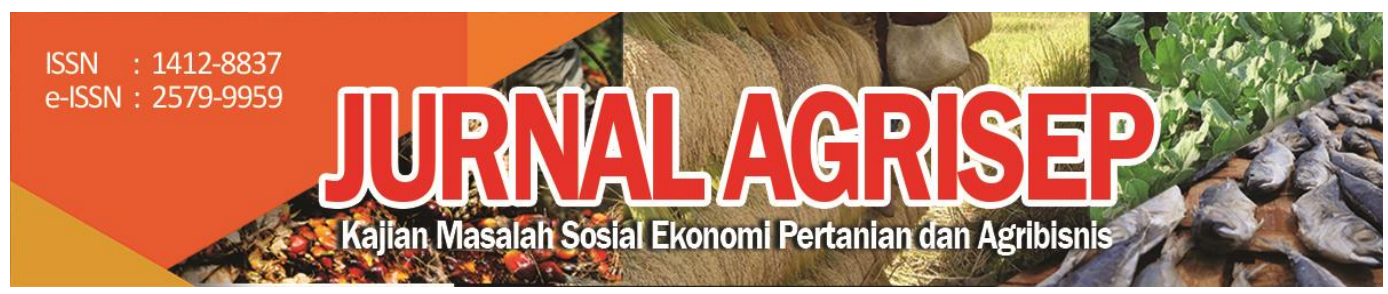

DOI: 10.31186/jagrisep.19.2.407-416

\title{
THE IMPLEMENTATION OF INTEGRATED CROPPING CALENDAR ON LOWLAND RICE FARMING IN BENGKULU CITY
}

\author{
M. Zulkarnain Yuliarso'); Nola Windirah ${ }^{2}{ }^{1)}$; Septri Widono ${ }^{3)}$ \\ ${ }^{122) 3)}$ Agricultural Socio-Economics Department Faculty of Agriculture \\ University of Bengkulu \\ Email: nolawindirah@unib.ac.id
}

\begin{abstract}
Bengkulu Province has rice productivity that is able to keep up with Lampung and West Sumatra (Top Five in production and on top three in land ownership throughout Sumatra), although rice farmland ownership is relatively low (less than 0.8 hectares)). The climate change issue in the last two decades has impacted a significant decrease in rice production in Bengkulu Province. The government offers the Cropping Calendar (Katam) program, a technology that is able to provide a various information related to the croping such as the prediction of the beginning of the rainy season, the beginning of the cropping season, cropping patterns, potential cropping area and others to overcome these problems and the City of Bengkulu has begun to implement the program. The purpose of this study is to analyze the level of application of integrated Cropping calendar by lowland rice farmers in Bengkulu City and analyze the correlation between internal and external factors of farmers with the level of Cropping calendar application. The basic method of this research is explanatory with a combined approach (quantitative and qualitative). The results showed that the level of application of integrated cropping calendar innovations in rice farmers was low. Farming experience, knowledge about cropping calendar, communication behavior, and social strengthening are significantly related to the level of application of cropping calendar innovation in rice farmers.
\end{abstract}

\section{ABSTRAK}

Provinsi Bengkulu memiliki produktivitas padi yang mampu mengimbangi Lampung dan Sumatera Barat (Lima Besar dalam produksi dan tiga besar dalam kepemilikan lahan se sumatera), meskipun penguasaan lahan padi relative rendah (kurang dari 0.8 hektar). Isu perubahan iklim dalam dua dekade terakhir berdampak pada penurunan secara signifikan terhadap produksi padi di Provinsi Bengkulu. Pemerintah 
menawarkan program Kalender Tanam (Katam) yakni teknologi yang mampu memberikan berbagai informasi tanam seperti prediksi awal musim hujan, awal musim tanam, pola tanam, luas tanam potensial dan lainnya untuk mengatasi permasalahan tersebut dan Kota Bengkulu telah mulai menerapkan program tersebut. Tujuan penelitian ini yakni untuk menganalisis tingkat penerapan Katam terpadu oleh petani padi sawah di Kota Bengkulu dan menganalisis hubungan antara faktor internal dan eksternal petani dengan tingkat penerapan Katam. Metode dasar penelitian ini yakni eksplanatori dengan pendekatan gabungan (kuantitatif dan kualitatif). Hasil penelitian menunjukkan bahwa tingkat penerapan inovasi Katam terpadu pada petani padi adalah rendah. Pengalaman usahatani, pengetahuan tentang Katam, perilaku komunikasi, dan penguatan sosial berhubungan nyata terhadap tingkat penerapan inovasi Katam pada petani padi

\section{INTRODUCTION}

Bengkulu Province is the lowest province in rice land ownership. However, the level of productivity is able to compensate Lampung and West Sumatra which are in the top five positions in total production and the top three in rice land ownership (Badan Pusat Statistik, 2019). This achievement can be the basis for giving special attention by various parties (government or researchers) to rice farmers in Bengkulu Province.

The issue of climate change continues to be in the spotlight in the last two decades and agriculture is the sector that receives the most serious impacts. Significant decreases in rice production have occurred in Bengkulu Province due to climate change (Balitbang, 2016). Local governments are encouraged to create a program that is able to overcome these problems. Integrated Cropping Calendar (Katam) Program is a technology offered by the government to rice farmers in obtaining various cropping information such as the prediction of the beginning of the rainy season, the beginning of the cropping season, cropping patterns, potential cropping area, fertilizer recommendations, fallow period, recommendations of rice varieties, potential for PPD attacks, areas prone to flooding and drought, the risk of production decreasing due to disasters (IAARD, 2016). Bengkulu City has a cropping calendar program for each village, where the application of the program offered by each sub-district is different due to the difference of the conditions of each region.

The Agency for Agricultural Research and Development (2016), Surmaini and Syahbuddin (2016) stated that in addition to reducing the risk of crop failure during climate change, the Integrated cropping calendar Program has other benefits, namely being able to increase rice productivity during normal climates. This is because there is an appropriate offer based on the criteria of each region, so the results obtained will be optimal.

The results of the Integrated Cropping calendar program socialization noted that there were 4 sub-districts or $44.5 \%$ suitability of the cropping schedule 
with the recommendations of the Integrated cropping calendar namely subdistricts of Muara Bangkahulu, Ratu Agung, Singaran Pati and Sungai Serut. Other subdistricts have not yet found suitability in cropping schedules which are allegedly due to the impact of extreme drought (Agricultural Research and Development Agency, 2016). The differences in these conditions encourage to find out more about the supporting factors of rice farmers in making decisions to apply the cropping schedule that has been recommended by the Integrated Cropping Calendar program. In addition, information on compatibility with the use of fertilizers, seeds and land area is needed.

Fachrista, et al (2013) found that socio economic factors were able to be a determinant of farmers in the adoption of government programs in terms of integrated crop management. The socio-economic factors that determine are education, land area, distance of settlements to rice farm, highways, input markets, and sources of technology. Kartono (2009) states that there is a factor in the level of farmers' cosmopolitanism, farmers' income, climate that supports farming, and information dissemination activities that can influence farmers' perceptions in the application of crop processing technology offered by the government. In other words, internal and external factors of farmers will be very closely related to the level of application of integrated cropping calendar technology offered by the Institute of Agricultural Technology Assessment as a competent institution in the introduction of technology to increase the productivity of rice farming in Bengkulu Province.

Based on the description above, the purpose of this study is to analyze the level of application of integrated cropping calendar by rice farmers in Bengkulu City and analyze the correlation between internal and external factors of farmers with the level of application of integrated cropping calendar.

\section{RESEARCH METHODS}

\section{Basic Methods and Research Techniques}

The basic method of this research uses explanatory methods with a combined approach (quantitative and qualitative). Combined methods are believed to neutralize or eliminate biases in one method and another. Qualitative research helps quantitative research in providing basic information about context and subjects, acts as a source of hypotheses, and helps scale construction. Quantitative approaches are used to analyze internal and external factors that influence the level of innovation adoption of rice farmers.

\section{Data and Data Sources}

The data used in this study are primary data and secondary data. Primary data were obtained from rice farmers in selected villages, key informants such as 
community leaders, relevant government elements, and other parties who were deemed to have credibility to provide information regarding integrated rice farming calendar activities. While secondary data obtained from the results of publications issued by various agencies and related institutions that can support the information needed in this study.

\section{Location and Sample}

The research location is Bengkulu City with the consideration that the City of Bengukulu has implemented the Cropping Calendar program. The sample was determined using 120 Quota Sampling techniques. Determination of supporting informants in the study was carried out by purposive sampling, with the consideration that the selected informants were people who were considered capable of providing the expected information (Bengkulu Agricultural Technology Assessment Agency (BPTP), sub-district BPP, village extension officers / village facilitators, and farmer group leaders).

\section{Methods of Data Analysis}

\section{Qualitative Analysis}

Qualitative procedures were performed using a model created by Miles and Huberman (1992) with stages 1) Data reduction, 2) Presentation of data, and 3) Drawing conclusions.

\section{Quantitative Analysis}

Rank-Spearman Correlation (Rs). Based on Siegel (1992), the calculation of the correlation coefficient Rs is systematically formulated as follows:

$$
r s=1-\frac{6 \sum_{i=1}^{N} d i^{2}}{N^{3}+N}
$$

Where: $\mathrm{rs}=$ Rank-Spearman correlation coefficient, $\mathrm{N}=$ Number of Respondents, $\mathrm{di}=$ Difference etween an independent variable with a ranking of the dependent variable, 6 = Constant, $\mathrm{i}=$ respondent order

The significancy test is done by comparing $t_{\text {stata }}$ with $t_{\text {tabled }}$ at significance level $95 \%$. To find the value of $t_{\text {value }}$ used the formula:

$$
t_{\text {stata }}=r s \sqrt{\frac{N-2}{1-r s^{2}}}
$$

Where $: \mathrm{rs}=$ Rank Spearman coefficient correlation, $\mathrm{N}=$ Number of Respondent 


\section{RESULT AND DISCUSSION}

\section{Implementation Level of Integrated Cropping Calendar in Lowland Rice Farmers}

Adoption is a process of changing the application or the using of new ideas or technology in a person after receiving the "innovation" that is conveyed. The application of this new innovation will certainly be different for each farmer. Integrated Cropping Calendar as an innovation in rice farming activities. The cropping calendar is made as a guide to rice ccropping time for extension workers and farmers in every district throughout Indonesia. chart below explains the distribution of farmers in implementing the integrated cropping calendar innovation.

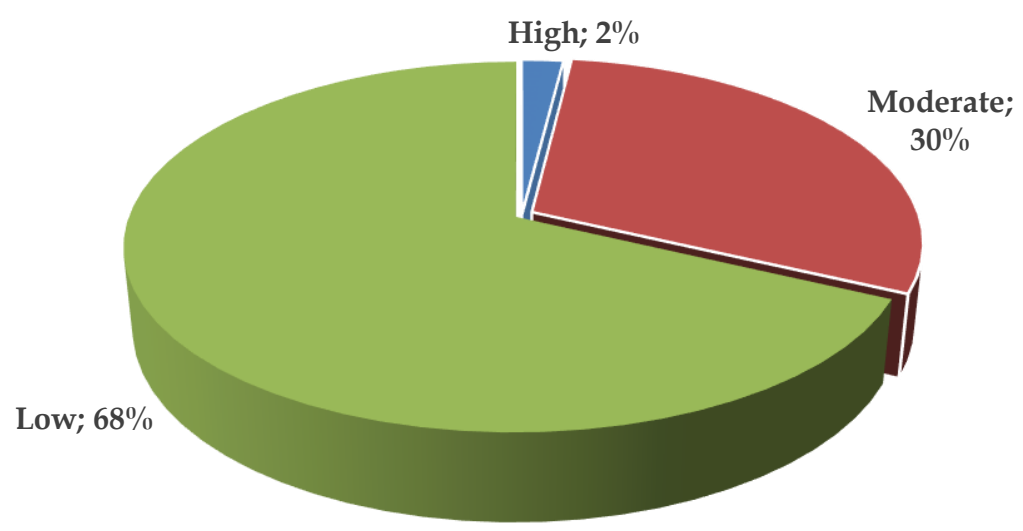

Figure 1.

Farmers distribution in implementing the integrated cropping calendar innovation

Source: Primary data, 2019

Based on Table 2 it can be explained that the level of application or adoption of farmers to the integrated cropping calendar of rice plants is still low, as much as $68 \%$ do not use the cropping calendar guidelines in their rice farming activities. Although the level of farmers' knowledge of the cropping calendar is very high, where $78 \%$ of farmers have a high level of Cropping Calendar knowledge, but the facts on the ground show the very opposite. This is related to the farmers' decision to only apply the cropping methods that they have been doing for generations. The habit of seeing their left and right neighbors in rice farming is also a factor that will directly influence their adoption of innovation 
decisions. The relatively long drought and limited infrastructure such as pumps are the reason why farmers cannot implement the full Cropping calendar technology package because it is related to irrigation problems. Only $2 \%$ of farmers apply a cropping calendar for rice farming. This is inseparable from the position of the farmer as the head of the farmer group. As chairman it is certain that they will emulate the latest innovations that come to them, hoping that they will be emulated by other group members.

Although the level of implementation of the full cropping calendar at the farmer level is still low, the technological components recommended in the integrated cropping calendar of rice plants have basically been implemented by farmers in Bengkulu City in their rice farming activities. The technology component is the use of superior varieties / seeds, both single and compound fertilization, application of jajar legowo cropping patterns.

\section{Factors Related to the level of Application of the Integrated Cropping Calendar in rice farming}

The application of an integrated planting calendar in rice farming in Bengkulu City is proven to be influenced by several factors that have been tested in this study. Table 10 shows the results of the correlation test for land area factors, farming experience, knowledge of catam, communication behavior, the role of extension workers, last year's acceptance, social strengthening of the level of calendar application in rice farming.

Tabel 1. Output of Rank Spearman Correlation Test

\begin{tabular}{lcc}
\hline \multicolumn{1}{c}{ Variable } & Correlation Coefficient & Sig. a \\
\hline Acre & 0,056 & 0,544 \\
Farming Experience & 0,177 & $0,018^{*}$ \\
Knowledge on Cropping Calendar & 0,221 & $0,015^{*}$ \\
Communication Behaviour & 0,297 & $0,001^{* *}$ \\
Extension Role & 0,021 & 0,820 \\
Revenue from Previous Year & $-1,40$ & 0,128 \\
Social Strengthening & 0,270 & $0,003^{* *}$ \\
\hline
\end{tabular}

Noted: $\left.\mathrm{n}=120,{ }^{*}\right)$ : Significant at $\left.\alpha=0,05, * *\right)$ : Significant at $\alpha=0,01$

Based on output the Correlation test Spearman Rank of 120 respondents there are several dependent variables that are significantly related. Variables related to Cropping Calendar Innovation Adoption are Farming Experience, Knowledge of Cropping Calendar, Communication Behavior, and Social Strengthening 


\section{Farming Experience}

The results of Correlation Coefficient analysis Spearman Rank between the variables of farm experience and the adoption rate of cropping calendar innovation are 0.077 with the probability for a two-party test of 0.018 . The test results show that there is a significant correlation between farm experience and the level of adoption of cropping calendar innovation, where the probability value is smaller than the significancy level $(0.018<0.05)$. The correlation seen from the correlation coefficient between farming experience and the adoption of cropping calendar innovation is positive. The correlation coefficient is 0.077 , so the correlation between the variables of farming experience with the adoption level of cropping calendar innovation is unidirectional and the correlation is very weak. This means that the more experience a person has in farming, the higher the interest in adopting cropping calendar innovations.

The more experienced someone in applying certain methods, the easier it will be to apply, to implement new methods even though technically is more difficult, it will become easier because they already have experience in farming. Farmers with longer experience will easily adopt a new innovation that is difficult to implement easily. This is in line with Soekartawi (2005) which says that farmers who have experience will be more advanced in carrying out farming activities. The decision to change the normal cropping system to the cropping calendar system will be very easy for experienced farmers. Nurfitri (2014) in her research said that the length of farming has an influence and is positively related to the level of adoption of new methods in agriculture. Nurfitri researched about the factors that influence farmers in adopting organic vegetable farming. It is said that someone with more farming experience has better technical experience than farmers who have less experience in farming operations. So, when confronted with the new SPO of farming, farmers can compare with farming methods that have been done previously.

\section{Knowledge of Cropping Calendar}

In Table 10. we can see the correlation coefficient Spearman Rank between the knowledge variables about cropping calendar and the level of adoption of cropping calendar innovation that is equal to 0.221 with a probability value of 0.015 . The test results show that there is a significant correlation between knowledge about cropping calendar with the level of adoption of cropping calendar innovation, where the probability value is smaller than the significancy level $(0.015<0.05)$. The correlation seen from the correlation coefficient between knowledge of cropping calendar with the adoption of cropping calendar innovation is positive, means that the direction and the correlation are in the criteria are very weak.

Sudarta (2002) said that farmers' knowledge is very helpful and supports their ability to adopt technology in their farming business and the sustainability 
of their farming business. The higher the level of knowledge of farmers, the ability to adopt technology in agriculture is also high, and vice versa. Farmers' knowledge will be related to the level of education of farmers themselves. Knowledge of the complete cropping calendar system owned by the farmer will encourage the farmer to adopt the innovation and vice versa, farmers who do not yet have knowledge of the cropping calendar system will tend to doubt even do not want to adopt this innovation. This is related to the mindset of the farmer, where with the knowledge of farmers will easier to accept input of new innovations that are useful for the progress of farming. In other words, without adequate knowledge, farmers cannot adopt cropping calendar innovations properly. This is in line with research conducted by Astuti et al (2016) regarding the factors that influence farmers' adoption of technological innovation in the sawong orange in Bengkulu Province. The results of the study stated that the level of farmers' knowledge of PTKJS innovations is very closely and positively related to the level of farmers' adoption of PTKJS innovations.

\section{Communication Behavior}

The results of Correlation Coefficient analysis Spearman Rank between communication behavior variables and the level of adoption of cropping calendar innovation are 0.297 with the probability for a two-party test of 0.001 . The test results show that there is a significant correlation between communication behavior with the level of adoption of cropping calendar innovation, where the probability value is smaller than the significancy level $(0.001<0.01)$. The correlation seen from the correlation coefficient between communication behavior with the adoption of katam innovation is positive. The correlation coefficient is 0.297 , so the correlation between the variables of communication behavior with the level of adoption of cropping calendar innovation is unidirectional and the correlation is sufficient.

Everyone will relate to certain people and sometimes ignore things that don't seem too important. Communication becomes a way in the delivery of it. In the process of adopting an agricultural innovation will be influenced by the communication behavior of the farmers themselves. Results in Table Xx. shows that the more often farmers take part in extension, long experience in farming, knowledge of cropping calendar is adequate, the better the communication network is formed and the higher the rate of adoption of cropping calendar innovation.

\section{Social Strengthening}

The Correlation Coefficient Spearman Rank in Table 10. between social reinforcement variables and the level of adoption of cropping calendar innovation is 0.270 with a probability value of 0.003 . The test results show that there is a significant correlation between social strengthening with the level of 
adoption of cropping calendar innovation, where the probability value is smaller than the significancy level $(0.003<0.01)$. The correlation that is visible from the correlation coefficient between the strengthening social innovation adoption cropping calendar is positive, it means the same direction and do qualify enough.

Main sources of information for a farmer are the family members, fellow farmers, neighbors, farmers succeed, caretaker of the farmers group, extension workers and other sources believed by farmers have reliable innovation information. Mulyandari et al (2005) that interpersonal media is the most dominant media used by farmers in accessing needed innovation information. The more complete the information and the higher the support received from all parties regarding the group system, the sustainability of the farming business will also be higher. It will also influence farmers to adopt and implement the cropping calendar system in their farming business.

\section{CONCLUSION AND SUGGESTION}

\section{Conclusion}

The conclusions that can be drawn from the results of the study are:

1. The level of application of integrated cropping calendar for rice farmers is low.

2. Farming experience, knowledge about cropping calendar, communication behavior, and social strengthening are significantly related to the level of implementation of cropping calendar innovation in rice farmers.

\section{Suggestion}

Suggestions given based on the situation and field conditions are:

1. The socialization of the implementation of the cropping calendar at the farmer level should be intensified through mentoring activities carried out by extension workers.

2. The availability of water for rice farmers is an absolute must be met to maintain the stability of farming. Provision of water pumps and wells in the rice field area is very important when farmers are faced with a drought which the cycles cannot be predicted.

\section{REFERENCES}

Astuti U P, D.Sugandi, Hamdan. 2016. Faktor-Faktor yang Memengaruhi Adopsi Petani terhadap Inovasi Teknologi Jeruk Gerga Lebong di Provinsi Bengkulu. Bengkulu.

Badan Penelitian dan Pengembangan Pertanian (Badan Litbang Pertanian). 2016. Laporan Akhir Gugus Kalender Tanam Terpadu di Provinsi Bengkulu. Badan 
Pengkajian Teknologi Pertanian Bengkulu. DIPA BPTP Bengkulu TA 2016.

Badan Pusat Statistik (BPS). 2019. Luas Panen, Produksi, dan Produktivitas Padi menurut Provinsi. https://www.bps.go.id/dynamictable/2019/04/15/1608/luas-panenproduksi-dan-produktivitas-padi-menurut-provinsi-2018.html, diunduh pada 18 Juli 2019.

Fachrista, Irma Audiah, Rachmat Hendayana, Rishaferi. 2013. Faktor Sosial Ekonomi Penentu Adopsi Pengelolahan Tanaman Terpadu Padi Sawah di Bangka Belitung. Jurnal Litbang Pertanian. 22(2): 113-120.

Kartono. 2013. Persepsi Petani dan Penerapan Inovasi Pengelolaan Tanaman dan Sumberdaya Terpadu Padi Sawah di Lokasi Prima Tani, Kabupaten Serang, Provinsi Banten. Tesis. Institut Pertanian Bogor.

Miles, B. M dan Huberman, M. 1992. Analisis Data Kualitatif Buku Sumber Tentang Metode-metode Baru. Jakarta: UIP

Mulyandari RSH, Rudi SR, Eko A.. 2005. Alternatif Model, Diseminasi Informasi Teknologi Pertanian Mendukung Pengembangan Pertanian Lahan Marginal. Prosiding Seminar Nasional Pemasyarakatan Inovasi Teknologi dalam Upaya Mempercepat Revitalisasi Pertanian dan Perdesaan di Lahan Marginal, Mataram, 30-31 Agustus 2005.

Nurfitri S. 2014. Tingkat Adopsi Teknologi Budidaya sayuran Organik oleh Petani Mitra ADS-UF IPB Serta Faktor-faktor yang Memengaruhinya. [skripsi]. Bogor (ID): Institut Pertanian Bogor

Siegel, S. 1992. Statistik Non Parametrik. Jakarta: Gramedia Pustaka Utama.

Soekartawi. 2005. Prinsip Dasar Komunikasi Pertanian. UI Press. Jakarta

Sudarta W. 2002. Pengetahuan dan sikap petani terhadap pengendalian hama terpadu. SOCA. 2(1):31-34.

Surmaini, Elza, Haris Syahbuddin. 2016. Kriteria Awal Musim Tanam: Tinjuan Prediksi Waktu Tanam Padi di Indonesia. Jurnal Litbang PertanianI. 35(2): 47-56.

416 | M. Zulkarnain Yuliarso, Nola Windirah, Septri Widono; The ... 